\title{
Hypertext device for forensic text in courtroom context
}

\section{Keyman Fuat* and Sade Kathrane}

Research Institute of Language Studies

*Corresponding author's email: keymanfuat@rils.org

\begin{abstract}
In a hypertext device for forensic text in courtroom context, the anchor rarely defines the nature of the link which it maintains with the target, the information to which it points. But navigation cannot be reduced to successive actions carried out on links. It is a rich and complex activity made up for the reader of defined waiting horizons, of cognitive patterns which are sometimes largely implicit and which function as frameworks of coherence. Thus, the hypertext link, which generates so much disorientation in an activity of information research and in the exploitation of documents with informative, explanatory or argumentative value, can turn out to be a formidable narrative efficiency in a narrative interactive. The interactive narrative is a particularly relevant object for understanding the way in which the frames inherited from a traditional form of reading are invested in the digital field, which are a source of coherence but which are simultaneously seen to be profoundly renewed by the exploitation of certain properties of hypertext devices for forensic text in courtroom context.
\end{abstract}

Keywords: hypertext device, forensic text, courtroom contetxt. 


\section{$\underline{\text { FULL TEXT }}$}

\section{APA CITATION:}

Fuat, K., \& Kathrane, S. (2020). Hypertext device for forensic text in courtroom context. Asian Journal of Law and Courtroom Practice, 15(1), 21-48.

\section{Disclosure statement}

No potential conflict of interest was reported by the authors.

\section{References}

Abel, R. L. (1982). The Politics of Informal Justice. New York: Academic Press.

Atkinson, J. (1979). Order in Court. Atlantic Highlands, NJ: Humanities Press.

Atkinson, J. (Eds.) (1984). Structures of Social Action. Cambridge: Cambridge University Press.

Attardo, S. (1990). The violation of Grice's maxims in jokes. In: Proceedings of the Annual Meeting of the Berkeley Linguistics Society, vol. 16. pp. 355-362.

Austin, J. L. (1962). How to Do Things with Words. Oxford: Oxford University Press.

Bashor, C. R. (1985). Small Claims Procedure in North Carolina, 51 Popular Government 31.

Gibbs, R. W., Moise, J. F. (1997). Pragmatics in understanding what is said. Cognition, 62, 51-74.

Grice, H. P. (1975). Logic and conversation. In: Cole, Peter, Morgan, Jerry L. (Eds.), Syntax and Semantics, vol.3. New York: Academic Press.

Levinson, S. C. (2000). Presumptive Meanings: The Theory of Generalized Conversational Implicature. Cambridge, MA: MIT Press. 
Shuy, R. W. (1998). The Language of Confession, Interrogation, and Deception. Thousand Oaks, CA: Sage.

Shuy, R. W. (2005). Creating Language Crimes: How Law Enforcement Uses (and Misuses) Language. Oxford: Oxford University Press.

Sinclair, M. B. W. (1985). Law and language: the role of pragmatics in statutory interpretation. University of Pittsburgh Law Review, 46, 373-420.

Stygall, G. (1994). Trial Language: Differential Discourse Processing and Discursive Formation. Amsterdam: John Benjamins.

Susanto, S., Zhenhua, W., Yingli, W., \& Nanda, D. S. (2020, January 13). Forensic Linguistic Inquiry into the Validity of FO as Discriminatory Potential in the System of Forensic Speaker Verification. https://doi.org/10.31226/osf.io/4y6tn

Susanto, S. (2016, May). Language in Courtroom Discourse. In International Conference on Education and Language (ICEL) (p. 26).

Tiersma, P. M. (1993). Linguistic issues in the law. Language, 69(1), 113-137.

Tiersma, P. M. (1999). Legal Language. Chicago: University of Chicago Press. 